\title{
Language Ideology of Tengger Community in Tutur District
}

\author{
H Hariyono ${ }^{1}$, P Handoko ${ }^{2}$, C T Suryawati ${ }^{3}$, C Pujimahanani $^{4}$ \\ \{bagushariyono@gmail.com ${ }^{1}$, putut.handoko@unitomo.ac.id ${ }^{2}$, tantrisuryawati@yahoo.com ${ }^{3}$ \}
}

${ }^{1,2,3,4}$ Dr. Soetomo University Surabaya, Indonesia

\begin{abstract}
This research entitled Language Ideology of Tengger Community in Tutur District focuses on one of the new trends called language ideology. The phenomenon of language ideology is also found in a district in Pasuruan city in the East Java Province. The district is Tutur where it is a haven for some remnants of native old Javanese of Hindu religion live in peace with the Muslims. This research is aimed at studying the proofs of language ideology is used in Tengger community in Tutur District in Pasuruan and how the language ideology maintains the self-identity in a certain community. The theories used in this research cover linguistic ideology or language ideology and speech community. This descriptive qualitative research made use of depth interview as a means of data collecting technique. Based on the research findings, this research studies that the awareness of religious revivalism in 1990s gives an implication of a need to have more piety and social cohesiveness among the Hindus in Tutur, and also the awareness to maintain their Hindus' identity by converting Islamic terms into Hindus' in which they can use in their own society as the language ideology.
\end{abstract}

Keywords: Language Ideology, Speech Community

\section{Introduction}

The attitude of human beings on using languages in practice has become interesting topics since the 1980's. The increasing of this phenomenon is related to the interest in studying language in social context as stated by George Yule in his The Study of Language with the emergence of various disciplines in linguistics. The interest of studying the relation between language and social context does not become the monopoly of the linguists but it becomes the intention of other experts, such as in the field of anthropology, sociology, and politics, and it even becomes the new blend of science that is interdependent.

One of the new trends of discussion is language ideology. Language ideology becomes an issue as an interdisciplinary subject that crosses linguistics, sociolinguistics, beliefs, politics, anthropology, etc. Paul Krokisty is one of the leading figures in this subject. He finds the phenomenon that in Tewa people in Arizona that the natives use the language of Tewa as an identity of the culture. This action conserves the language from the subjugation from the surrounding people. From his analysis, it can be said that language ideology is created to maintain certain beliefs in a society. Once again that must be noted that language ideology is also related to sociolinguistics and linguistic anthropology as well. 
The phenomenon of language ideology is also found in a district in Pasuruan town in the East Java Province. The district is Tutur where it is a safe haven for some remnants of native old Javanese of Hindu religion live in peace with the Muslims. Pasuruan is traditionally a Muslim town with the majority speak Javanese and some speak Madurese. It has 24 districts where Tutur becomes the only district that has Hindus population in three villages among its 12 villages. The three villages are Ngadirejo, Andonosari, and Kayukebek. In Ngadirejo, the Hindus constitute around 50 percents of the population, while in the later two villages, they are only around 20 percents. The Hindus call themselves as the Tengger peoples in which some of them have become Muslims recently since 1980's. The Muslims in three villages are mainly Javanese and also from the new converts.

The harmonious life among the Tengger from different faiths has shown that the local wisdom has maintained the principle of unity in diversity as a value among people in Nusantara. The process of maintaining the Hindus identity among the Tengger Hindus and their harmony with their brother Muslim neighbors, especially the Tengger Muslims is also reflected in the use of language as a language ideology. The language ideology becomes the self-identity in maintaining social cohesion among Hindus and Muslims. of Tengger people.

From the explanation above, it can be formulated that this research is aimed at studying the proofs of language ideology is used in Tengger community in Tutur District in Pasuruan and how the language ideology maintains the self-identity in a certain community.

\section{Theoretical Background}

Michael Silverstein defines language ideology as beliefs about language mediate between language use and social organization[1], [2]. According to Silverstein, language ideology is related to sets of beliefs about language articulated by users as a rationalization or justification of perceived language structure and use. Therefore, it can be said that language ideology is created as an effort by a community to maintain the values as the community perceives as a rationalization about their identity. Another theorist, Kroskity, pays interest in how language use is closely connected to linguistic culture, cultural identity, and ethnohistory. The interconnections among them become a way to maintain a language and shift on it.

Becausethis research studies how language is used in the community, therefore this research uses sociolinguistics for this research.Spolsky[3], [4] states that sociolinguistics is alive within its geographical, and social setting and space so that this research investigates that the object of this study deals with how a speech community practices a language within a certain social setting and space.

Describes a speech community as a group of people who share a set of norms and expectations regarding the use of language, it can be stated that speech community can be aware of the existence of sameness and differences among the individuals, in which this condition causes the existence of linguistic variable. Hymes states that the linguistic variable or linguistic boundaries cannot be understood from the basis of linguistics alone, because attitudes and social meanings attached to those items also count[5]. Therefore, a speech community cannot be separated from what values they have. The values can be determined by education and occupation[6], ethnicity and race [6], religion[5], gender [6].

The differences in those above values cause the different language utterances within a speech community. Spolsky shows the possibility of the existence of the differences in phonology and grammar and lexical ones[7]in which all of them become the repertoire. The richness of repertoire of a speech community is valued within the context of linguistic ideology or language ideology. 
This research belongs to descriptive qualitative in nature. research made use of in-depth interview as a means of data collecting technique. In-depth interviewing is a qualitative research technique that involves conducting intensive individual interviews with a small number of respondents to explore their perspectives on a particular idea, program, or situation. The interview was conducted in August 2017. There were interviewees as the source of information.

\section{Analysis}

The Hindus in Tutur speak Javanese with a strong Tenggerese variant as the Muslims in Tengger do. But, interestingly since 1987, during the reign of Suharto, there has been a massive attempt of religionizing the Hindus and Muslims in Tengger as part of preventing what Suharto thought that irreligious people were communist supporters. Before 1987, the Hindus in Tutur were a unique Hindu community with their own tradition that was and is different from the Hindus in Bali. The Hindus in Tengger lacked knowledge about the rich Hindu's gods where the Balinese know well, and the most important thing is that there is no caste system in the Hindus in Tengger. In 1987, Mr. Yoto, a Hindu teacher, has been sent by the Ministry of religion to teach Hinduism there. Gradually the more knowledge of Hinduism is known by them so that the awareness of being Hindus are getting better as this condition got along with the same awareness that exists among their Muslim brothers.

Because of their close contacts with their Muslim brothers when the awareness of becoming religious is more apparent, the Hindus come closer to imitate the muslim tradition in which the tradition cannot be found in the other Hindus community and this also creates the Hindus community has more cohesiveness. This imitation can be seen in the religious activities, such as greeting, gathering to hear the sermon, enjoying meal after the funeral with prayer, and belief on communicating with the dead before the dead are buried. The Muslims use the term Assalammualaykum as greeting, pengajian or pengaosan for gathering to hear the sermon, tahlilan for enjoying meal after the funeral with prayer, and talqin for belief on communicating with the dead before the dead are buried. These all activities are copied by the Hindus as two reasons, such as a means to increase the spiritual needs and another is, while using these activities, they convert them by using the Hindu's terms, so that the process of Hinduization of the activities work smoothly. The Hindus change Assalammualaykum by using the Hindu's word Wiwaha Samskara. In traditional Hindus in Bali, Wiwaha Samskara is used for a wedding ceremony, but the term is used by the Hindus in Tutur as a greeting as the Muslims do in Assalammualaykum. The other things arethat dharma shanty becomes a substitution for pengajian, puja pitara substitutes tahlil, and permalam for talqin. The Hindus realize that the terms are produced as a marker of their community different from their Muslim brothers. Therefore, it can be said that there is a strong awareness of using the terms as a language ideology because the language that is used is a part of belief that is used in the social world. The Hindus and the Muslims, besides their close relationship and harmony, are also proud of their distinctness.

\section{Conclusion}

By presenting the facts, this research studies that the awareness of religious revivalism in 1990s gives an implication of a need to have more piety and social cohesiveness among the Hindus in Tutur, and also the awareness to maintain their Hindus' identity by converting Islamic terms into Hindus' in which they can use in their own society as the language ideology. 


\section{References}

[1] I. Piller, "Language Ideologies," in The International Encyclopedia of Language and Social Interaction, Hoboken, NJ, USA: John Wiley \& Sons, Inc., 2015, pp. 1-10.

[2] I. Piller, "Naturalization language testing and its basis in ideologies of national identity and citizenship," Int. J. Biling., vol. 5, no. 3, pp. 259-277, Sep. 2001.

[3] B. Spolsky, Sociolinguistics. Oxford: Oxford UP, 2010.

[4] B. Spolsky, "Sociolinguistics of Literacy, Bilingual Education, and Tesol," TESOL Q., vol. 16, no. 2, p. 141, Jun. 1982.

[5] R. Wardhaugh, An Introduction to Sociolinguistics. Malden: Blackwell, 2006.

[6] G. Yule, The Study of Language. Cambridge: Cambridge UP, 2007.

[7] Alessandro Duranti, Linguistic Anthropology, First Publ. USA: Cambridge University Press, 1997. 